\title{
СУЧАСНИЙ ПОГЛЯД НА ВИКЛАДАННЯ КІНОРЕЖИСУРИ ЯК ДИСЦИПЛІНИ
}

Кінорежисура, так само як у иілому кіноіндустрія, зазанає постійного впливу нових технологій. Система викладання у профільних вищих навчальних закладах має надавати адекватну відповідь до таких вимог і наближати навчальний проиес до реалій сучасного аудіовізуального виробництвв. Стаття презентує погляд авторів на цю проблему та певні висновки з накопиченого практичного досвіду.

Ключові слова: кіно, кінорежисура, вища освіта, методи навчання.

Film directing is under influence of new technologies the same as the entire film industry. The system of student education at high institutions requires the appropriate answer to these permanent changes in order to bring the process closer to the modern audiovisual environment. In this paper authors share the practical experience of several relevant educational techniques.

Keywords: cinema, film directing, high education, education techniques.

Кинорежиссура, как и вся киноиндустрия, находится под постоянным влиянием новых технологий. Система обучения студентов в профильных высших учебных заведениях должна дать адекватный ответ этим требованиям и приблизить процесс обучения к современным реалиям аудивизуального производства. Статья представляет взгляд авторов на данную проблему и содержит ряд выводов из накопленного практического опыта преподавания.

Ключевые слова: кино, кинорежиссура, высшее образование, методы обучения.

Майже непомітно і «безболісно» у вітчизняному кінематографі промайнула технологічна революція і «кіношна спільнота» «прокинулась» у світі цифрових технологій. Світ, що його вже давно опанували кінематографії інших країн. I якщо засвоєння сучасного цифрового аудіо-відео інструментарію не така вже й складна процедура, то підготовка, навчання та виховання вітчизняних режисерів - професіоналів у кіносвіті — має часом «класичний» характер, а зміна умов існування аудіовізуального простору вимагає інших підходів та інших, сучасних методик опанування фаху.

IT-технології вже стали невід'ємною частиною кіновиробництва, а підготовка спеціалістів, які поєднують технічну грамотність і креативність творчого підходу, часом, на жаль, все ще лежать у площині «Ноme Video». Реалії сьогоднішнього кіновиробництва - це новітні технології, котрі потребують і відповідних фахівців. Режисер, як ніхто інший, зобов'язаний знати, що таке сучас- на аудіовізуальна культура. Вирішення багатьох творчих проблем має йти через опанування майбутніми режисерами всіх компонентів ремесла.

Але від початку — трішки історії вітчизняного кіновиробництва. На 1991 рік на теренах України фунціюнували 22723 (!) кінодемостраційні установи (кінотеатри, клуби, мобільні комплекси і т.д.), працювали п'ять заводів «Кінап», котрі продукують специфічне обладнання для функціонування галузі. В місті Шостка працював надпотужний хімічний комбінат «Свема», забезпечуючи потребу в кіноплівці не лише кінематографії СРСР, а й значну частину виробництва фільмів у Східній Європі. Вісім кіностудій України (різних видів кінопродукції) щорічно наповнювали екрани кінопрокату і телебачення фільмами власного виробництва, одночасно виборюючи левову частину «союзних» призів і нагород на численних міжнародних форумах та фестивалях. Щоправда, фінансувалось, а відповідно й контролювалось, 
це системою держзамовлення 3 центром у Москві - Держкіно СРСР. Але обсяги кількості щорічно створюваних кіностудіями України стрічок вражають уяву: сам лише «Київнаукфільм» іноді за рік випускав до 300-400 фільмів різноманітного виду та жанрового розмаїття. Решта студій не завжди могли похвалитися такими обсягами, але, природно, намагалися дотримуватись умовного поділу на види кінопродукції. I це обумовлювало специфіку навчання. Для студій готував творчий склад єдиний на той час вищий навчальний заклад України - кінофакультет Київського університету театру кіно і телебачення імені I. К. Карпенка-Карого. Відповідно, державне замовлення на підготовку фахівців планувалось і виконувалось за цільовим призначенням. Режисери-«ігровики» навчались у майстернях «метрів» від ігрового кіно. Випускники документальних і науково-популярних чи «телефільмових» майстерень поповнювали лави відповідних студій.

Зрозуміло, що на той час працювала така модель абсолютно адекватно. Хоча певні обмеження в ефективності специфіки процесу лежали в двох вимірах. Перший - майстер-художній керівник створював на курсі культурне середовище, в якому індивідуальності студентів взаємозбагачувались культурним надбанням кожного, і другий особистий вплив майстра, його смакові та фахові особливості формували часом непогано підготовленого... теоретика в різноманітних мистецьких течіях і особливостях творчого почерку класиків від Ейзенштейна до Тарковського, Фелліні чи Тарантіно... Ну, а на питання «як робити кіно» відповідь - «на високому ідейно-художньому рівні», а в практичній площині головний методологічний посил майстра — «роби, як я». 3 огляду на вкрай обмежений ресурс можливості реалізації власних екранних робіт (кіноплівкова технологія не 3 дешевих) студент, як правило, лише на третьому (!) році навчання міг спробувати здобуті теоретичні викладки втілити в екранні роботи. При цьому результат — «розповзання» теорії і практики часом бував приголомшливий! Все, що так до ладу виглядало на папері, екран нівелював, виявляючи чи не головну ваду такої системи організації процесу підготовки кінорежисера: абсолютне ненабуття практичних навичок - ремесла!

А на календарі XXI століття! Вже «цифрова ера». Зміна технологій дала можливість змінити й процес фахової підготовки режисерів кіно. Здавна напрацьована методика, що вправно працює вже не один десяток років в американських та й у значній частині європейських кіношкіл, стала доступною у вітчизняній кіноосвіті. Доступність і відносна дешевизна цифрових фото- та відеокамер дала змогу вирішувати чимало проблем. Отже вже і в нас поєднання теорії і практики нарешті стало можливим, починаючи із засвоєння елементів усієї палітри режисерських технологій i набуття практичних навичок. Плутанина з побудовою розкадровки зйомочного епізоду діалогу двох персонажів, так званої «вісімки», стає «каменем спотикання» до моменту «власноручно» створеного 2-5 хвилинного епізоду - вправи з усіма виробничими етапами: написання сценарію епізоду, паперової розкадровки, зйомки і складання в монтажній програмі. Декілька таких вправ (бажано 3 «ускладненням» - спілкування трьох-пяти персонажів чи однокадрова «вісімка») і професійні навички студента вже стають органічними в наборі виразних елементів режисерських технік. Таких «екранізованих» вправ у процесі засвоєння професії кінорежисерського фаху, на наш погляд, має бути не менше двох десятків, і основна частина має бути реалізована протягом перших 2-3-х років навчання за програмою бакалаврату. Подібні вправи не заміняють, а лише доповнюють щосеместрові короткометражні фільми з повним циклом міні-виробничого процесу від заявки до копії. При цьому це стосується будь-якого виду чи жанру стрічки - залежно від навчальної програми та спеціалізації.

Один 3 найяскравіших російських режисерів пострадянського кіно Борис Хлебніков, порівнюючи методики навчання в кіношколах Ізраїлю, США, Франції і ВДІКу, слушно зауважив: «в останньому майстри не вчать професії. Адже перше завдання - на кшталт того, що робить інструктор з водіння. Той випрацьовує в учня чіткий рефлекс - коробка передач, зчеплення, газ, гальма, праворуч, ліворуч... А вдіківські викладачі, не навчивши своїх студентів елементарним речам, наприклад, розкадровці, починають розповідати про Тарковського і високе мистецтво. Ось ми $з$ вами розмовляємо, і в цій кімнаті знаходяться інші люди... Як розкадрувати цю сцену? Я б зараз про це довго думав, а у студента американської кіношколи в голові вже $є 15$ готових схем, яким його навчили, і йому залишається обрати одну 3 них. Якщо він майбутній Коппола, то вигадає шістнадцяту, сімнадцяту, вісімнадцяту...» [1].

Ось такий нелегкий спадок комплексу методик залишився нам від «єдиноправильної» системи «всесоюзної кузні кінокадрів»... А ми й досі дивуємось: і чому це наші фільми інколи виглядають «штучними» і де ця природність і органіка 
в елементарній побудові простих сцен та епізодів, немовби на екрані не кіно з притаманним йому тяжінням до реалістичності, а театральне дійство зі своєю специфічною умовністю, але ж усе це в переважній більшості - зона відповідальності режисера.

Режисура кіно, операторська майстерність, драматургія, монтаж, майстерність актора - основні складові фахової майстерності режисера, але без розуміння сучасних «кіномовних» тенденцій і новітніх екранних технологій у сьогоднішньому світі кіноіндустрії професіоналові буде вкрай важко... 3 огляду на це студентові режисерського фаху вже з першого курсу вкрай важливо з застосуванням практичних завдань і вправ опанувати основи суміжних професій - драматурга, оператора, звукооператора, монтажера продссера, що дає можливість від «паперового» навчального процесу перейти до «екранної» реалізації хоча б на рівні етюдів чи вправ. Саме для цього керівник курсу-викладач, інколи штучно формуючи кіногрупу розподіляє «ролі» 3 кола однокурсників режисерської майстерні за принципом - у цій роботі ти «продюсер» колега - «режисер монтажу», наступний - «асистент режисера» і.т.д. У роботі над фільмом іншого студента відбувається зміна «ролей», і так рухається «по колу».

Програмне наповнення другого та третього року навчання та професійні дисципліни традиційно «працюють» за сталою і давно вже відпрацьованою схемою, і ця система достатньо життєздатна. Хоча певне «ноу-хау» і тут є в досвіді кінорежисерських майстерень. Традиційно студенти кінорежисерських спеціалізацій три роки опановують на сценічному майданчику всі премудрості акторської майстерності та навички роботи режисера 3 актором і не актором, і кінцевий результат кожної сесії - сценічні етюди, мінівистави в умовних обставинах аудиторії з нехитрим реквізитом, приблизними костюмами і ширмами, що «грають» стіни, ліс, а інколи навіть... море! Цифрові відеотехнології сьогодні дають змогу перенести частину навчального процесу безпосередньо на екран, наблизивши процес до максимально реалістичного середовища і отримуючи при цьому нову якість результату.

Традиційна плівкова структура студійного виробництва передбачала наявність на кожній студії власної кінолабораторії з окремими технологічними підрозділами - установки світла та кольору під час друку позитивних кіноматеріалів, цех комбінованих зйомок з оптичною трюк-машиною, що давала можливість робити міжкадрові «напливи», штучні «рапіди» чи багатошарові експозиції. Окрім того, - титрувальний підрозділ зі специфічним оптичним агрегатом, який займав простір понад 50 квадратних метрів. Мультстанок 3 покадровою камерою - теж не надто компактний пристрій $з$ масою заліза, що важив не менш ніж сучасний автомобіль. Ще один студійний цех, котрий, окрім основних операций із запису музики й тексту, вирізнявся потужним технологічним комплексом устаткування, яке часом займало 2(!) поверхи і забезпечувало зведення всіх плівкових фонограм на один носій, який потім 3 магнітної плівки друкувався на оптичну доріжку кінокопії. Але вінцем всієї цієї технологічної армади, що забезпечувала процес створення фільму в монтажно-тонувальному процесі (постпродакшн), був монтажний цех теж з робочою станцією, що його лише умовно можна було назівати «монтажний стіл». Насправді ж це більше нагадувало великий заводський токарний верстат - i за розмірами, i за вагою, бо кіноінженери та розробники чавуну на цей «гаджет» не жаліли.

І ось уся ця інженерна кавалькада 3 оптичного скла, лампової електроніки та металу, котра вірою й правдою слугувала всім кінематографістам понад 100 років, майже водночас виявилась... металобрухтом! А всі операції з обробки зображення та звуку опинились у комп'ютерному «сундучку» або ще краще - в мобільному ноутбуці. Отже і навантаження на режисера чи режисера монтажу зросло, точніше функціональні можливості й спектр палітри виразних можливостей значно розширилися.

I тут починається найцікавіше - не так вже й давно фахові виші, готуючи спеціалістів для кіно, взагалі цим не переймались. Знов-таки з теорією монтажу начебто все в порядку, а навчити в будь-якій програмі «клацати» на міжкадрові склейки можна на одній-двох парах, але оперувати комплексом нового спектра можливостей у новітніх творчо-технологічних реаліях... тут і в 2-3 роки вкластися непросто, бо засвоєння виразних можливостей технічних засобів і технологій не $\epsilon$ таким вже й складним завданням. Проблемою насправді стає оперування цими можливостями для досягнення найкращого результату. I базова основа цього - все багатство загальної культури й традицій світової культури.

Сьогоднішні обсяги виробництва фільмів в Україні, на жаль, незіставні $з$ минулими чи навіть 3 кількістю стрічок, що їх знімають щорічно в кінематографічних країнах з потужною і налагодженою інфраструктурою кіно-відео-телепро- 
кату та сферою виробничих послуг. I, отримавши диплом кінорежисера, вчорашній студент у пошуку реалізації своїх навичок і вмінь часом може постати перед вибором, який обумовлений реальними потребами та вакансіями сьогоднішнього ринку праці, простіше кажучи на телебаченні, чи у новітніх структурах, котрі освоюють Інтернет-простір. А там мистецька складова, на відміну від традиційного кіно, займає не таку вже й велику нішу. Готувати студента до потенційної можливості опинитись у такій ситуації - теж завдання, яке ще вчора не було актуальним. Закладати вміння працювати в різних телеформатах. Засвоїти специфіку створення ТВ-проєктів різноманітних видів та жанрів, вміння орієнтуватись у тематичній політиці різних каналів хоча 6 на теоретичних засадах сьогодні вельми актуально. I, звичайно, спробувати розібратися в тенденціях і можливостях відеодизайну, візуальних ефектах, композитингу 2D чи 3D-анімації - просто необхідні умови виховання і підготовки «універсального солдата» мультимедійного «аудіовізуального фронту».

Ринкові умови і майже докорінна зміна умов системи фінансування кіногалузі змінили практично всі процеси і психологію режисерського мислення. На вітчизняному кінопросторі потроху з'являються професіонали новітньої формації продюсери. 3'явились незвичні для вітчизняного кіно терміни в пакетах паперів, що супроводжують творчі документи, - product placement, pitching, медиафраншиза... Нині, за умовами часу, режисер, окрім своїх професійно-творчих і технічних знань, має орієнтуватися в світі економічних «можливостей» (чи «неможливостей») своїх проєктів. Він повинен бути обізнаним у сфері юридичного законодавства, а саме - знати та захищати свої (та суміжні) авторські права, відповідно до Закону України, він повинен орієнтуватись у складних змінах, що відносяться до подат- кових фінансових інституцій (скажімо, йдеться про спонсорські гроші та правила їх оподаткування). Тобто, готуючи свій проєкт, режисер має прорахувати всі «за» $\mathrm{i}$ «проти», однак і це ще не головне. Реалізація вже готового фільму (в нинішніх умовах) теж часом лежить на плечах режисерів I тут виходить на поверхню обізнаність режисеpa $з$ психологією як інструментом, що допоможе йому орієнтуватися в перипетіях часу. Тому курси «Психологія управління», «Авторське право», «Менеджмент і маркетинг», «Продюсер у кіно» стають поряд з основними фаховими дисциплінами, бо режисерський маркетинг - це вміння продавати не конкретний фізичний товар, а ідею; точніше - сукупність ідей: СВІТОГЛЯД.

P. S.: Може скластися хибне уявлення, що автори, аналізуючи переваги та недоліки чинної в мистецьких вузах системи побудови навчання в творчих майстернях, надають перевагу потоковому процесу, до якого прагнуть адепти Болонської системи. Категорічне ні! Лише творчі майстерні з яскравими лідерами-професіоналами 3 власним індивідуальним професійним досвідом можуть і повинні виховувати і випускати яскраві й несхожиі особистості, якінаділені повним обсягом ремісницьких навичок професіонала. А досягти цього можна, лише збільшивши кількість часу на індивідуальні години спілкування та консультацій. В іншому разі можна отримати загони уніфікованих роботів «від мистецтва». I хто від цього виграє в кінцевому результаті?

\section{Джерела та література}

1. Сергей Семенов «Сумасшедший неореализм». «Эксnерт», № 44, 2012.

\section{References}

1. Semenov, S. (2012). Crazy neorealism. «Expert», vol. 44 [in Russian]. 